and Shoe Research Association on the modification of New Zealand fish liver oils for the production of chamois leather has yielded a process for utilizing vegetable oils in oil-tanning which, besides producing stronger leather, enables white washable gloving leather to be obtained without bleaching. Bark from Pinus radiata has been proved to be a possible source of tannin, and the detrimental effect of high temperatures upon pickled pelts in storage and transport has been demonstrated. The investigations by the Pottery and Ceramics Research Association indicate that for ceramic manufacture deposits of ball clays from Canterbury, Otago and Southland are equal in quality to any such deposits found elsewhere in the world.

\section{OCEANOGRAPHY IN THE UNITED STATES}

IN 1927 the United States National Academy of Sciences appointed a Committee to consider the share of the United States in a world-wide programme of oceanographical research. Much of the Committee's report was published in book form under the title "Oceanography : Its Scope, Problems and Economic Importance", by Henry B. Bigelow (1931). One of the major outcomes of the decisions of that Committee was the building and endowment of the Oceanographic Institution at Woods Hole, and there was a general all-round increase in marine research.

In 1949 a second Committee on Oceanography was established by the National Academy. The reason for the setting up of this second body was not lack of interest in oceanography. Owing to the recognition of the practical applications of oceanography during the Second World War, marine research had, in fact, flourished; but it was chiefly government sponsored. As a result of inflation and the heavy cost of maintenance of modern research ships and equipment, private endowments were entirely inadequate, and research could only continue at its present scale with heavy government support. The Committee considered that "the healthy growth of oceanography has been hampered by the uncertainty as to how long this support may be available, and by other restrictions". It was to report on this situation that the Committee was appointed. Its report, entitled "Oceanography 1951", is now published".

As in the previous report, the relations of the science to biology, geology and meteorology, and certain recent notable advances, are surveyed. The advance in physical oeeanography has been very striking. That this is so is largely due to the War, which has resulted in the provision of "a nucleus of 80 to 100 physical oceanographers in this country, compared with perhaps half a dozen prior to 1930 . ... More than half of the funds being expended for oceanographic investigations at the present time come from the Department of Defence".

The sea is a source of food, and it is necessary to ensure that research is also directed towards increasing the yield from the sea fisheries, as well as gaining knowledge useful in war. The annual yield of the

- National Academy of Sciences-National Research Council. Pub llention 208: Oceanography 1951; a Keport on the Present Status of the Science of the Sea by the Committee on Oceanography of the National Academy of Sciences. Pp. vil +36 . (Washington, D.C. National Academy of Sclences-National Research Council, 1952.) world's fisheries is quoted as twenty million tons, giving only one-fiftieth of the total protein consumption, yet half the world's population has a diet seriously deficient in protein. The Committee considers that "Heretofore most fishery research programmes were attempted on too small a scale. This was due to lack of appreciation of the complexity and magnitude of fishery problems, so that insufficient funds were assigned to many projects". Recently, however, there have been large-scale attacks on certain problems, such as the causes of the disappearance of the Californian sardine; the potentialities of the pelagic fisheries of the central North Pacific; and the movements of the Gulf Stream.

But the Committee considers that oceanography is not developing in a well-balanced manner and that there is almost no financial support for general marine biology. It thinks that inadequate attention is being paid to many challenging problems which do not have military significance and do not bear on specific fisheries ; and it feels that, in order to ensure more freedom of research into such basic problems, greater private financial support is needed. At the same time, government support on a liberal and far-sighted basis should be continued, to provide the large-scale co-ordinated effort which the size and complexity of oceanic phenomena demand. Through the United Nations and President Truman's Point Four Programme, the United States should also encourage the development of oceanography in other countries, and especially in the southern hemisphere and western Pacific. The Committee recommends the securing of private funds for the provision of research fellowships at existing nceanographic institutions; for facilities for visiting investigators ; for the provision of more permanent posts ; and to supply increased funds for operating ships and for basic research in biology and chemistry.

The present total income of institutions in the United States carrying out oceanographical research is about 2,300,000 dollars, four-fifths of which is supplied by the government. It is recommended that the additional funds from private sources should be between 500,000 and 750,000 dollars. This would bring the total annual expenditure on oceanographical research into the region of one million pounds sterling by those laboratories other than the Federal and State organizations.

F. S. Russell

\section{PRESERVATION OF THE LAKE DISTRICT}

$\mathrm{T}$ HE Report and News Letter for August of the Friends of the Lake District* records a discouraging year, and refers particularly to the absence of a Joint Planning Board except in name for the Lake District National Park and to the hobbling of that authority by the failure to appoint a planning officer for the Park. The practical consequences of this position are concisely and clearly indicated, as well as the requirements for the effective functioning of any joint board. Local matters on which the Report and News Letter comment are the assurance received from the superintendent of the Eskmeals military range that the proposed night firing is, in

- Friends of the Take District. Report and News Letter, August. Pp. 20. (14 Princes Street, Ulverston, 1952.) 